\title{
PHYTODIVERSITY OF MIDFIELD BALKS (ENVIRONMENTAL ISLANDS) IN A SELECTED AREA IN NORTH-WEST POLAND
}

\author{
GAMRAT, R. $.^{*}-$ GAŁCZYŃSKA, M. ${ }^{2}-$ SOTEK, $Z^{3}{ }^{3}$-STASIŃSKA, M. ${ }^{3}$ \\ ${ }^{1}$ Department of Ecology, Environmental Protection and Management, West Pomeranian \\ University of Technology, Stowackiego 17, PL-71-434 Szczecin, Poland \\ ${ }^{2}$ Department of Chemistry, Microbiology and Environmental Biotechnology, West Pomeranian \\ University of Technology, Stowackiego 17, PL-71-434 Szczecin, Poland \\ (e-mail: Malgorzata.Galczynska@zut.edu.pl; phone: +48-91-449-6322) \\ ${ }^{3}$ Department of Botany and Nature Conservation, University of Szczecin \\ Felczaka 3c, PL-71-412 Szczecin, Poland \\ (e-mails: sotek@univ.szczecin.pl, stasinsk@univ.szczecin.pl; phone: +48-91-441-5650) \\ *Corresponding author \\ e-mail: Renata.Gamrat@zut.edu.pl; phone: +48-91-449-6343 \\ (Received $21^{\text {st }}$ Jan 2018; accepted $30^{\text {th }}$ May 2018)
}

\begin{abstract}
In the years 2007-2009 the differentiation of flora on the area of balks of different length was assessed. The studies of flora were carried out in the area of 7772 ha of Ińsko Lakeland in Poland. For the detailed studies 72 balks were chosen, formed from roadsides and divided into two groups according to the length. Topographic maps in the scale 1:10 000 were used for the assessment of earlier functions of the studied objects. It was shown that in the areas of an arable surface characteristic of average farms as regards their size in the European Union, the size of arable land and the length of balks related with it had an influence on phytodiversity. Despite the fact that the number of phytocoenoses was larger on shorter balks, their specific poverty did not affect biodiversity significantly. The presence of a large number of melliferous species influenced not only phytodiversity of balks, but it also resulted in the improvement of nutritive conditions, among others, for bees. A larger number of plant species on long balks, including also melliferous and therapeutic species, proves correct management of the production space in a long time period.
\end{abstract}

Keywords: fields, flora, Ińsko Lakeland, phytocoenoses, bees, melliferous and therapeutic plants

\section{Introduction}

In the middle of the 19th century a change of the production space started leading to its rationalization and intensification (introduction of mineral fertilization, soil reclamation, simplified crop rotation, land integration). These changes resulted in the reduction of species diversity in the cultural landscape (Kędziora et al., 2012; Pe'er et al., 2014; Horta et al., 2015). Cultivation of old species of wheat (einkorn wheat, emmer wheat, spelt, Polish wheat and club wheat), wild rye, bristle oat, millet, buckwheat and multispecies crops: flax, hemp, tobacco and hop was discontinued in favour of monocultures: wheat, maize, rye. There was a change in the density of boundary nature objects such as balks and midfield roads and other forms of environmental islands. The term "environmental islands" was coined in 1967 by McArthur and Wilson. It describes surface objects, such as: groups of trees, water ponds, water-free pits and grasslands. Polish researchers have extended the scope of this definition to cover the linear forms as well: drainage ditches, roadsides and farmbounds (Loster, 1991; Ratyńska, 2002; Karg, 2003, 2005; Symonides, 2010). Balks, i.e. narrow, uncultivated strips of grass 
vegetation participate, due to their location, in maintaining biological diversity of agricultural landscape, constituting valuable habitats for plants (Štefanová and Š́lek, 2014).

In order to maintain biodiversity in monoculture cultivation it is important not to apply chemical plant protective agents on the fringes of the fields. Dobrzański (2009) shows that on large plantations the width of individual fields should not exceed $100 \mathrm{~m}$, and that of balks $1 \mathrm{~m}$, which inclines towards maintaining areas of increased fragmentation. A positive aspect of land consolidation is reduction of the cost of the performed cultivation and limitation of potential neighborhood conflicts. However, land fragmentation makes it possible to lower the risk related to spatial variability of meteorological conditions and natural catastrophes (Penov, 2004; Di Falco et al., 2010). According to Kazlauskaite-Jadzevice et al. (2016), for the purpose of preserving biodiversity, the traditional Lithuanian landscape should be maintained and even further developed, particularly on highly undulating areas (Feiza et al., 2008; Kinderiene and Karcauskiene, 2016).

The quality of soils in the European Union is strongly differentiated, from quite fertile brown soils in the west to weak podsol soils in the central part (Directive, 2004). In the countries of the "old" EU, the process of food production is strongly mechanized and is of an intensive character. For example, in Great Britain 95\% of agricultural acreage belongs to the farms of the surface exceeding 20 ha. Larger fragmentation is observed in the south of Europe, e.g. in Greece, Portugal and Italy. The differentiation of the surface of plots depends on the size of a farm, the degree to which the field works were mechanized (Noga, 2005). An average size of arable land in the EU changed depending on the number of membership countries (for example the EU -15: 23 ha, and currently the EU - 27: 13.8 ha).

Taking into consideration the diversity of economic and social conditions in the European Union, the arable land in the North-West Poland was taken for the study. In the area set for the study, the most dominant were brown soils with farms of an average size of $21 \mathrm{ha}$. In the EU agricultural and environmental programs according to package 9 (of the buffer zone), the emphasis was laid on the protection of land against pollution of agricultural origin. Such function is played, among other things, by midfield balks which also results in maintaining biodiversity. Considering these regularities it was assumed that fragmentation of arable land will affect the diversity of balks. In view of the above, the aim of the study was to assess the differentiation of flora in the area of balks of different length. The usability of flora as bee nutrients was also studied and the presence of therapeutic species was determined.

\section{Material and methods}

\section{Study object}

In the years 2007-2009 the studies of flora were carried out in the area of 7772 ha of Ińsko Lakeland in Poland. This mesoregion is characterised by a diversified terrain relief with moraine hills of steep slopes and of considerable relative heights. Wet dells occur there as well as numerous lakes and rivers. This mosaic of diversified habitats is additionally enriched by an irregular course of boundaries between fields and forests (Borzyszkowski et al., 2016). The arable land in the studied area constituted above $60 \%$ of the surface and is dominated mainly by soils of complex 4 and 5 , i.e. by very good and good rye soils, determined as leached brown and acid ones. In the structure of the 
surface layer of soils, light loamy and heavy loamy sand prevailed (Gamrat, 2012). An average surface of arable land in this area amounted to 21 ha, which reflects approximate conditions in the European Union.

\section{Analysis of flora}

For the detailed studies 72 balks were chosen, formed from roadsides and divided into two groups (36 objects in each group) according to the length: I - up to $500 \mathrm{~m}$, II $>500 \mathrm{~m}$ (Fig. 1). The width of the balks varied from 50 to $70 \mathrm{~cm}$. Topographic maps in the scale 1:10 000 were used for the assessment of earlier functions of the studied objects.

According to the description prepared by Dzwonko (2007), 72 phytosociological releves were taken and used for the identification of 11 vegetation communities determined in the synthetic table which refers to shorter and longer balks. The surface of releves varied from $10(0.5 \mathrm{~m} \times 20 \mathrm{~m})$ to $14 \mathrm{~m}^{2}(0.7 \mathrm{~m} \times 20 \mathrm{~m})$. The species composition of the plans was also analysed with reference to their usability as bee nutrients (along with defining their melliferous potential and length of flowering), additionally the occurrence of therapeutic species was also assessed (including ornamental, cosmetic and edible ones).

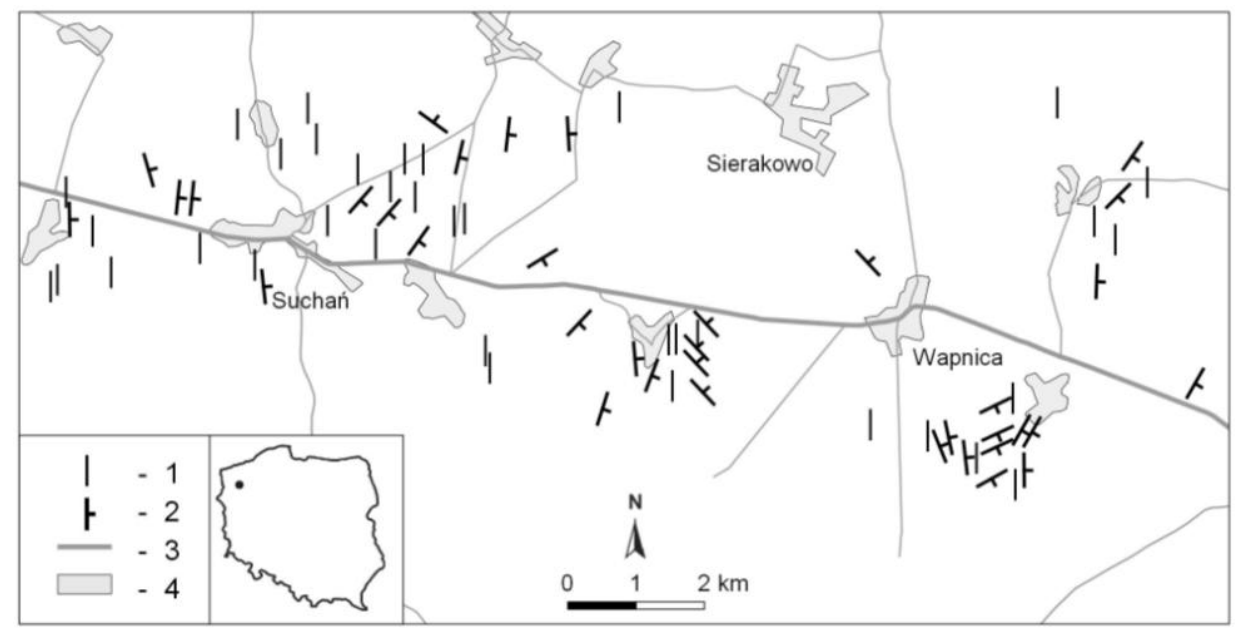

Figure 1. A schematic map showing studied balks on the Ińsko Lakeland. (1 - short balks, 2 long balks, 3 - roads, 4 - buildings)

\section{Analysis of melliferous plants}

The species of plants found at the balks were classified according to Lipiński (2010) and Pogorzelec (2018) as a food base for bees, i.e. giving their values of honey yield $[\mathrm{kg} / \mathrm{ha}$ or $\mathrm{kg} / \mathrm{tree}$ or bush] and the time of flowering. Floristic observations were made during floristic studies. The frequency of bees on melliferous plants was determined: 3 frequent, 2 - weak, 1 - sporadic or presence of other pollinators, $\mathrm{x}$ - no insects were observed (Table 3).

\section{Statistical analysis}

The results concerning the number of plant species occurring on the balks were developed on the basis of the univariate analysis of variance. Additionally, such factors 
as the complex, type of soil and surface layer were tested. The significance of differences was evaluated using the Tuckey's test at the significance level $\alpha=0.05$. For the isolated groups of balks the linear relationship was determined between the number of all the species of plants and the number of plant species according to their sociological belonging. All statistical analyses were performed with Statistica 12 PL software (Statsoft).

\section{Results}

In the studied area 102 species of plants were observed, of which balks from group II (of the length of the object amounting to $916 \mathrm{~m}$ ) were characterised by higher phytodiversity ( 89 species). Shorter balks showed a 1.5 times decreased number of plant species (59).

Out of the species isolated according to their sociological belonging, ruderal species dominated (53 species). There was a smaller number of meadow species (39 species). Triticum aestivum L. was shown as an agricultural species. Trees and shrubs occurred rarely, there were individual specimens: Alnus glutinosa Gaertn., Betula pendula Roth., Crataegus monogyna Jacq., Prunus domestica L., P. padus L., Rubus caesius L., $R$. idaeus L., Salix alba L., except for Sambucus nigra L. which formed a vegetation patch in the area of one object.

Large diversity of the number of species at 72 isolated research objects resulted in the observation of statistically significant differences between the average number of species on the balks of group I (8) and group II (11). Such diversity was not recorded as regards agricultural and ruderal trees and shrubs. In the case of meadow species - their larger number occurred on the long balks (Fig. 2).

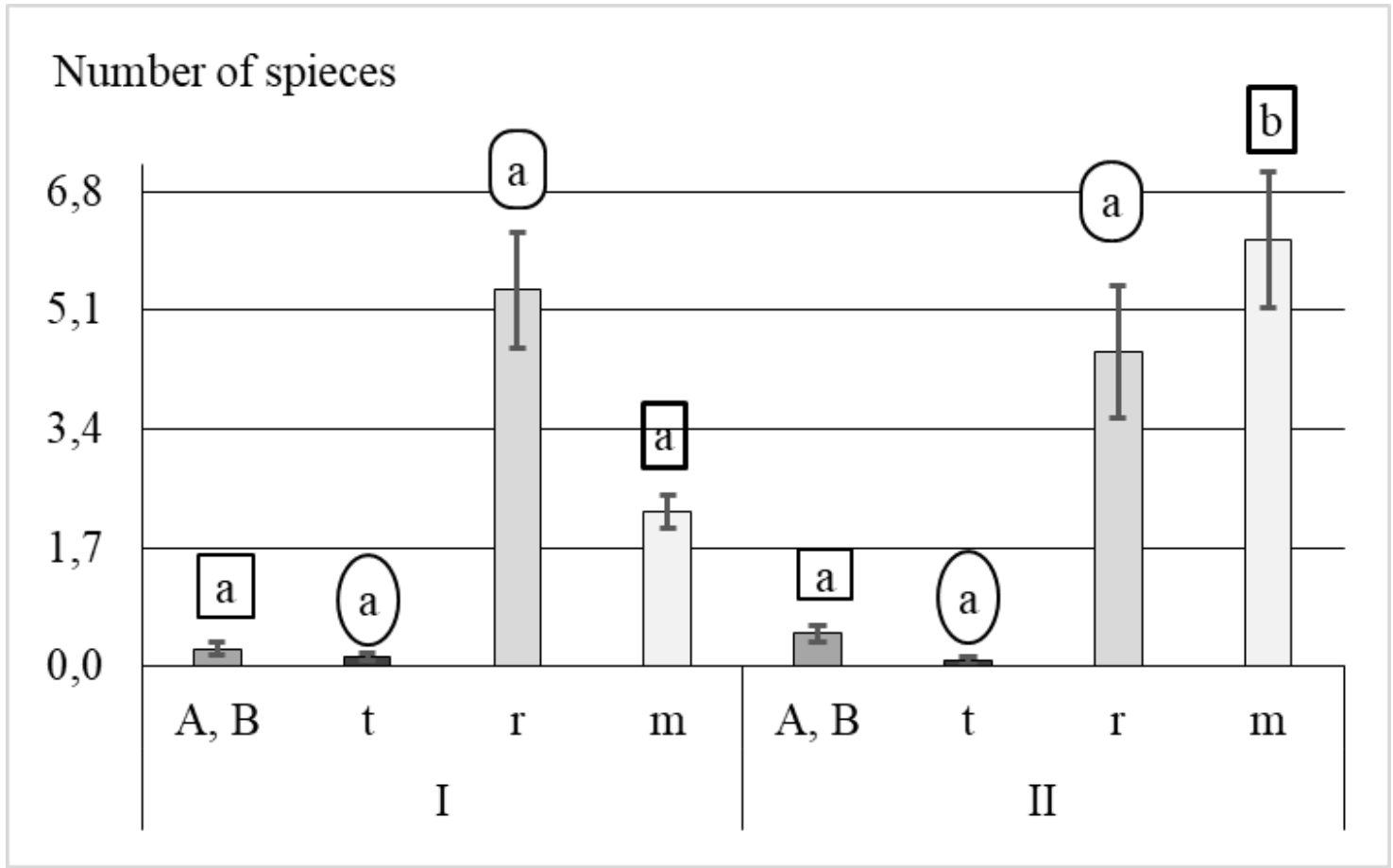

Figure 2. The number of plants on the balks. (I - group of balks (short), II - group of balks (long), A, B - trees, shrubs, $t$ - tillage species, $r$ - ruderal, $m$ - meadow) 
Arable land of good agricultural quality constitutes about $2 / 3$ of the studied area. However, considerable diversity of the terrain both in the period when PGRs (State Agricultural Farms) functioned to the year 1989 and at present were not conducive to a large consolidation of arable land. This fact had an influence on the diversity of this landscape.

The largest number of ruderal species according to sociological groups (Table 1) was characteristic of the very weak rye-lupine complex (complex 7).

Table 1. The mean number of plant species according to their nationality sociological

\begin{tabular}{c|c|c|c|c|c|c|c|c}
\hline \multirow{2}{*}{ Group } & \multicolumn{4}{|c|}{ Soil complexes } & \multicolumn{2}{c|}{ Soil type } & \multicolumn{2}{c}{ Mechanical composition of the soil } \\
\cline { 2 - 8 } & $\mathbf{2}$ & $\mathbf{4}$ & $\mathbf{5}$ & $\mathbf{7}$ & $\mathbf{l b}$ & $\mathbf{a b}$ & lls & lss \\
\hline $\mathrm{G}$ & $11.0^{\mathrm{a}}$ & $8.2^{\mathrm{a}}$ & $9.8^{\mathrm{a}}$ & $21.0^{\mathrm{a}}$ & $9.0^{\mathrm{a}}$ & $11.0^{\mathrm{a}}$ & $11.0^{\mathrm{a}}$ & $8.0^{\mathrm{a}}$ \\
$\mathrm{A}, \mathrm{B}$ & $0.3^{\mathrm{a}}$ & $0.3^{\mathrm{a}}$ & $0.5^{\mathrm{a}}$ & $1.0^{\mathrm{a}}$ & $0.3^{\mathrm{a}}$ & $0.6^{\mathrm{a}}$ & $0.5^{\mathrm{a}}$ & $0.2^{\mathrm{a}}$ \\
$\mathrm{t}$ & $0.1^{\mathrm{a}}$ & $0.1^{\mathrm{a}}$ & $0.2^{\mathrm{a}}$ & $0.0^{\mathrm{a}}$ & $0.1^{\mathrm{a}}$ & $0.3^{\mathrm{b}}$ & $0.1^{\mathrm{a}}$ & $0.1^{\mathrm{a}}$ \\
$\mathrm{r}$ & $4.8^{\mathrm{a}}$ & $5.0^{\mathrm{a}}$ & $4.2^{\mathrm{a}}$ & $15.5^{\mathrm{b}}$ & $4.7^{\mathrm{a}}$ & $5.7^{\mathrm{a}}$ & $5.0^{\mathrm{a}}$ & $5.0^{\mathrm{a}}$ \\
$\mathrm{m}$ & $5.8^{\mathrm{a}}$ & $2.9^{\mathrm{a}}$ & $5.0^{\mathrm{a}}$ & $4.5^{\mathrm{a}}$ & $4.1^{\mathrm{a}}$ & $4.4^{\mathrm{a}}$ & $5.2^{\mathrm{a}}$ & $3.0^{\mathrm{b}}$ \\
\hline
\end{tabular}

Group: G - General, A, B - trees, shrubs, $\mathrm{t}$ - tillage species, $\mathrm{r}$ - ruderal, $\mathrm{m}$ - meadow

Soil type: $\mathrm{lb}$ - leached brown soil, ab - acid brown soil

Mechanical composition of the soil: lls - light loamy sand, lss - loamy sand strong

In the studied area leached brown soils dominated (74\%) in the surface layer with light loamy sands (54\%). The diversity of the type of soils and their mechanical composition in the surface layer did not influence the number of species: trees and shrubs and green species from ruderal habitats. The type of soil influenced the number of agricultural species and the mechanical composition of soils had an influence on the number of meadow habitats.

In both groups of balks a statistically significant correlation was observed between the general number of plant species and the number of those from ruderal habitats (Figs. 3 and 4). A stronger relation occurred for the area of balks from group I (0.96) than from II (0.70).

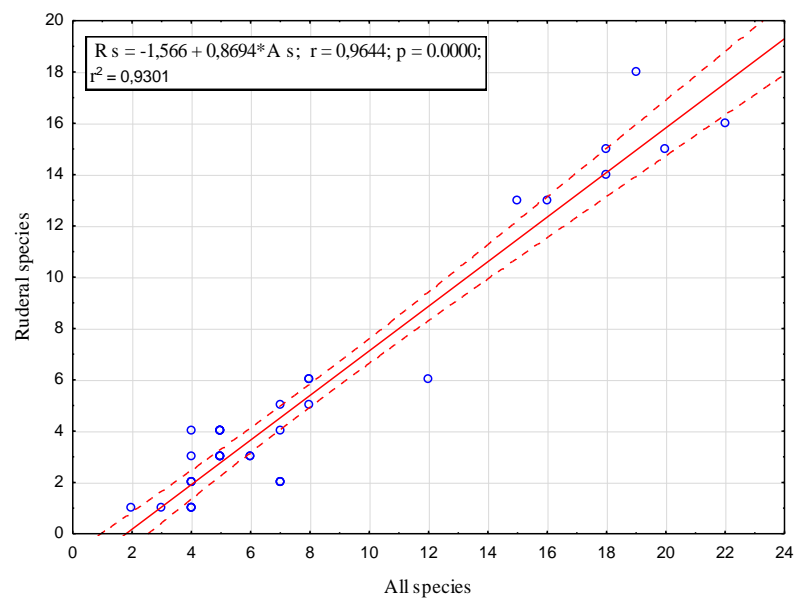

Figure 3. Relationship between number of all species and ruderal species (balks I) 


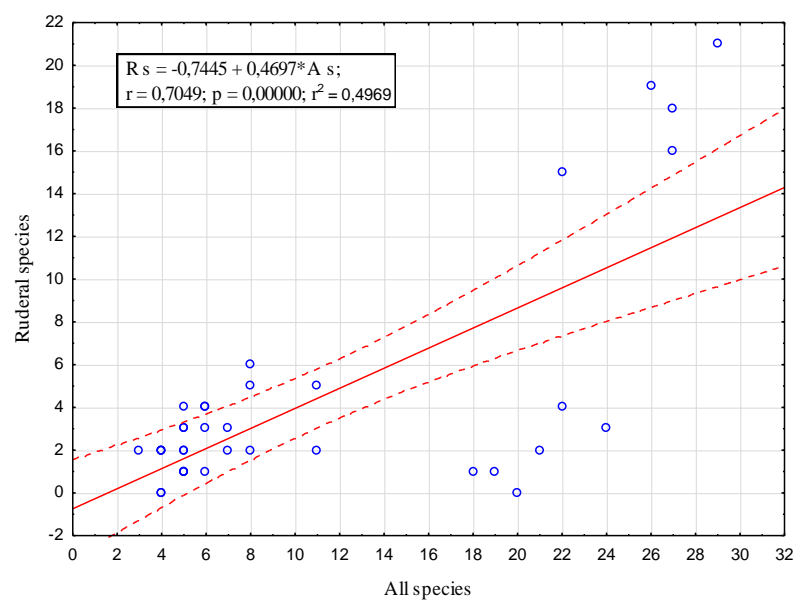

Figure 4. Relationship between number of all species and ruderal species (balks II)

In the case of longer balks (group II) additionally a significant linear dependence was observed between the number of plant species and the number of those from meadow (Fig. 5). In regression, the $r^{2}$ coefficient of determination is a statistical measure of how well the regression line approximates the real data points. It should be noted that in the case of longer baulks only slightly below $50 \%$ was explained by the positive correlation between the number of all species and ruderal species or between the number of all species and meadow species (coefficient of determination was from 50 to 46\%).

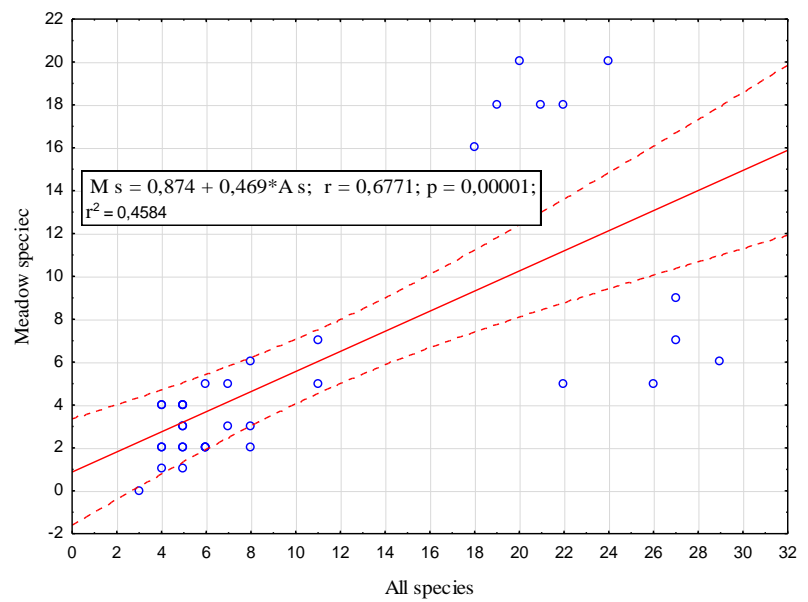

Figure 5. Relationship between number of all species and meadow species (balks II)

In the area of all the objects analysed from the phytosociological angle, 11 communities were found, including 10 in the area of shorter balks.

Out of phytocoenoses (marked with a grey colour) the most frequent were phytocoenoses of the grasses: community Lolium perenne (25 objects) and association Agropyretum repentis (18 objects). Other gramineous phytocoenoses were not so numerous: community with Dactylis glomerata (7 objects), with Apera spicae-venti (6 objects) and with Agrostis capillaris and Arrhenatheretum elatioris (4 objects Table 2). 
Table 2. Characteristics of communities studied balks

\begin{tabular}{|c|c|c|c|c|}
\hline Sort of balks & Lo & alks & Sho & balks \\
\hline & $\mathbf{S}$ & D & $\mathbf{S}$ & D \\
\hline Constancy $\mathrm{S}$-Coefficient $\mathrm{D}$ for 36 phytosociological releve's & & & & \\
\hline I. ChCl. Molinio-Arrhenatheretea*, ChO. Arrhenatheretalia elatioris & & & & \\
\hline Lolium perenne $D$ & II & 3244 & II & 2701 \\
\hline Dactylis glomerata & I & 604 & I & 2604 \\
\hline Arrhenatherum elatius & I & 1000 & I & 1944 \\
\hline Lotus corniculatus & I & 4 & I & 660 \\
\hline *Lathyrus pratensis & I & 70 & I & 590 \\
\hline Achillea millefolium & I & 208 & I & 1611 \\
\hline Pastinaca sativa & II & 49 & I & 1750 \\
\hline Taraxacum officinale & $\mathrm{I}$ & 132 & I & 778 \\
\hline Heracleum sphondylium & . & . & I & 340 \\
\hline Trifolium repens & I & 14 & I & 104 \\
\hline ChO. Plantaginetalia majoris & & & & \\
\hline Agrostis capillaris D & I & 257 & . & . \\
\hline Plantago major & I & 292 & I & 243 \\
\hline Poa annua & I & 14 & I & 243 \\
\hline ChO. Molinietalia caeruleae & & & & \\
\hline Cirsium oleraceum & II & 83 & I & 486 \\
\hline Deschampsia cespitosa & I & 340 & . & . \\
\hline II. ChCl. Agropyretea intermedio-repentis & & & & \\
\hline Elymus repens & $\mathrm{I}$ & 1903 & II & 3604 \\
\hline Equisetum arvense & I & 69 & I & 486 \\
\hline Convolvulus arvensis & . & . & I & 1507 \\
\hline III. ChCl. Stellarietea mediae & & & & \\
\hline Apera spica-venti & I & 868 & I & 972 \\
\hline Chenopodium album & I & 222 & I & 1056 \\
\hline Capsella bursa-pastoris D & I & 69 & I & 1264 \\
\hline Lactuca serriola D & I & 69 & I & 1507 \\
\hline Linaria vulgaris & I & 69 & I & 1507 \\
\hline Tripleurospermum inodorum & I & 104 & I & 1076 \\
\hline Erigeron canadensis D & I & 63 & I & 972 \\
\hline Papaver rhoeas & I & 14 & I & 729 \\
\hline Polygonum aviculare & I & 111 & I & 292 \\
\hline Chamomilla recutita & I & 70 & I & 243 \\
\hline Rumex crispus D & . & . & I & 535 \\
\hline IV. ChCl. Artemisietea vulgaris, SCl. Artemisienea* & & & & \\
\hline Artemisia vulgaris & I & 292 & II & 3056 \\
\hline Urtica dioica & I & 618 & I & 1944 \\
\hline Rumex obtusifolius & I & 14 & I & 1507 \\
\hline Cirsium arvense & I & 83 & I & 4861 \\
\hline *Oenothera biennis & I & 69 & I & 1701 \\
\hline *Picris hieracioides D & . & . & I & 1750 \\
\hline *Verbascum thapsus D & I & 69 & I & 1750 \\
\hline
\end{tabular}




\begin{tabular}{|c|c|c|c|c|}
\hline *Galeopsis pubescens & . & . & I & 1507 \\
\hline *Melilotus officinalis & I & 69 & I & 1458 \\
\hline *Medicago lupulina $\mathrm{D}$ & . & . & I & 1264 \\
\hline *Ballota nigra & I & 14 & I & 1215 \\
\hline *Malva sylvestris & I & 42 & I & 722 \\
\hline *Cirsium vulgare & I & 14 & I & 486 \\
\hline *Berteroa incana & I & 14 & I & 292 \\
\hline *Arctium lappa & I & 69 & I & 2431 \\
\hline *Lamium album & $\mathrm{I}$ & 14 & I & 1458 \\
\hline \multicolumn{5}{|l|}{ SCl. Galio-Urticenea } \\
\hline Fallopia dumetorum & I & 69 & I & 1750 \\
\hline \multicolumn{5}{|l|}{ Others } \\
\hline Sambucus nigra b & I & 97 & I & 340 \\
\hline Prunus domestica b & . & . & I & 347 \\
\hline Salix alba a & I & 14 & I & 292 \\
\hline Alnus glutinosa $\mathrm{b}$ & I & 14 & I & 243 \\
\hline Triticum aestivum & I & 525 & I & 632 \\
\hline
\end{tabular}

Sporadic species - I: Alchemilla pastoralis, Agrostis stolonifera, Bromus hordeaceus, Matricaria discoidea, Crepis biennis, Cynosurus cristatus, Daucus carota, Festuca rubra, Juncus articulatus, J. effusus, J. inflexus J. tenuis, Lysimachia nummularia, Plantago lanceolata, Phleum pratense, Potentilla anserina, Rumex acetosa, Vicia cracca (1), Lysimachia vulgaris (1, 2); II: Falcaria vulgaris (1), Tussilago farfara, Bunias orientalis (2); III: Anagalis arvensis, Centaurea cyanus, Consolida regalis, Lamium purpureum, Fallopia convolvulus (1); IV: Anthriscus sylvestris, Silene latifolia, Solidago canadensis (1, 2), Aegopodium podagraria, Cichorium intybus, Rubus caesius b, Tanacetum vulgare (1), Artemisia absinthium (2); Others: Anthoxanthum odoratum, Betula pendula a, Calamagrostis epigejos, Centaurea scabiosa, Crataegus monogyna b, Galium verum, Jasione montana, Prunus padus b, Rubus idaeus b, Rumex acetosella, Sedum acre, Thymus serpyllum, Trifolium arvense, T. campestre (1), Gnaphalium sylvaticum (2)

Cl. - class, O. - order; constancy, Ch. - characteristic species, I-V - order number, S: I - proportional participation of species < $20 \%$, II $-40-20 \%$, III $-60-40 \%$, IV $-80-60 \%$, V - 100-80\%; D - the coefficients of cover (from 1 to 8750 ) were estimated for 36 phytosociological releve's; . not present

The indicated species belonged to 10 phytosociological classes, 2 subclasses, 17 orders. The most numerous were the species of meadow and ruderal habitats (respectively Molinio-Arrhenatheretea class - 33 and Artemisietea vulgaris - 25 species) and segetal ones (Stellarietea mediae class - 16 species). The species of ruderal habitats that formed numerous patches were, among others: Artemisia vulgaris L. (D-3056), Urtica dioica L. (D-1944), Picris hieracioides L., Verbascum thapsus L., Fallopia dumetorum (D-1750), Galeopsis pubescens Willd., Rumex obtusifolius L. (D-1507). As to the meadow species, the following were presentt in large numbers: Dactylis glomerata L. (D-2604), Lolium perenne L. (D-3244, 2701), Arrhenatherum elatius (L.) P. Beauv. ex J. \& C. Presl (D-1000, 1944), Achillea millefolium L. (D-1611). At present, numerous species from segetal habitats were, among others: Lactuca serriola L., Linaria vulgaris Mill. (D-1507), Capsella bursa-pastoris (L.) Medik. (D-1264), Tripleurospermum inodorum (L.) Sch. Bip. (D-1076). Less numerous, as far as species are concerned, however often present, were: Agropyretea intermedio-repentis class, Koelerio glaucae-Corynephoretea canescentis and Epilobietea angustifolii in a form of the following species: Elymus repens (L.) Gould (D-1903, 3604) and Convolvulus 
arvensis L. (D-1507). Species belonging to other phytosociological classes (FestucoBrometea, Rhamno-Prunetea, Salicetea purpureae, Trifolio-Geranietea sanguinei) occurred in small numbers (from 1 to 3 species).

Herbal plants were classified according to the way of their use as: food base for bees (67), therapeutic (64 species), ornamental (22 species), cosmetic (15 species), and seasoning herbs (22 species). Despite the domination of grass communities, there were also numerous dicotyledonous species with a melliferous function (Table 3).

Table 3. Frequency of bees on melliferous plants found in the examined areas together with the value of honey yield [ $\mathrm{kg} / \mathrm{ha}$ or $\mathrm{kg} / \mathrm{tree}$ or bush] and the time of flowering beginning

\begin{tabular}{|c|}
\hline Frequency of bees/name of the plant species/values of honey yield \\
\hline Melliferous plants flowering in spring (from March) \\
\hline $\begin{array}{l}{ }^{3} \text { Lamium album }(368) *,{ }^{3} \text { Taraxacum officinale }(200),{ }^{3} \text { Salix alba } \mathrm{a},{ }^{3} \text { Rubus idaeus } \mathrm{b}(\text { po } 150),{ }^{3} \\
\text { Lamium maculatum }(140),{ }^{3} \text { Prunus domestica } \mathrm{b}(43),{ }^{3} \text { Lamium purpureum }(38),{ }^{2} \text { Berteroa incana, }{ }^{2} \\
\text { Capsella bursa-pastoris, },{ }^{1} \text { Alnus glutinosa } \mathrm{a}, \mathrm{b},{ }^{1} \text { Betula pendula } \mathrm{a},{ }_{1}^{1} \text { Sambucus nigra } \mathrm{b},{ }^{\mathrm{x}} \text { Prunus padus } \mathrm{b} \\
(25),{ }^{\mathrm{x}} \text { Crataegus monogyna } \mathrm{b}(15),{ }^{\mathrm{x}} \text { Tussilago farfara },{ }^{\mathrm{x}} \text { Linaria vulgaris, },{ }^{\mathrm{x}} \text { Rumex acetosella }\end{array}$ \\
\hline Melliferous plants flowering in summer (from June) \\
\hline 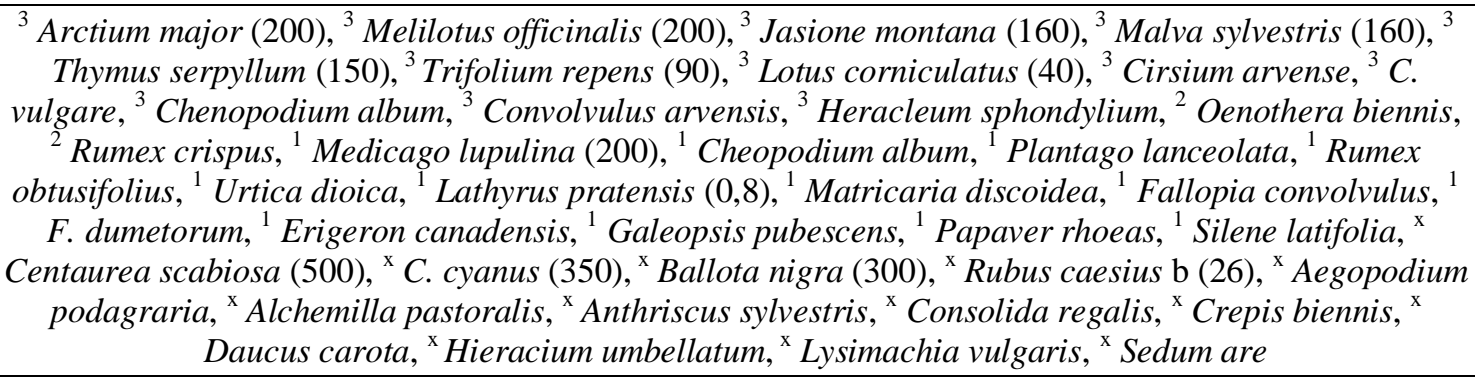 \\
\hline Melliferous plants flowering in autumn (from August) \\
\hline
\end{tabular}

${ }^{3}$ Cirsium oleraceum (500), ${ }^{3}$ Cichorium intybus (40), ${ }^{3}$ Verbascum thapsus, ${ }^{1}$ Pastinaca sativa, ${ }^{1}$ Picris hieracioides, ${ }^{\mathrm{x}}$ Solidago canadensis (700), ${ }^{\mathrm{x}}$ Trifolium arvense (30), ${ }^{\mathrm{x}}$ Artemisia absinthium, ${ }^{\mathrm{x}}$ A. vulgaris, ${ }^{\mathrm{x}}$ Galium verum

${ }^{3}$ - frequent, ${ }^{2}$ - weak, ${ }^{1}$ - sporadic or presence of other pollinators, ${ }^{\mathrm{x}}$ - no insects were observed, ${ }^{*}$ values of honey yield yield $[\mathrm{kg} / \mathrm{ha}$ or $\mathrm{kg} / \mathrm{tree}$ or bush]

This species on the fields are a valuable food base for bees, especially when the cultivated species are no longer flowering, i.e. in spring and late summer. The flora of the balks are numerous species on which bees forage for a long time, for example from March to September or October, and are also characterized by high honey yield values. They are the so-called common "weeds" (grasshopperdead-nettles, shepherd's purse and sorrel). In summer, the main species begin to flower, including those that bloom from June to October (including: Erigeron canadensis (L.) Cronquist, Galeopsis pubescens Willd., Hieracium umbellatum L., Malva sylvestris L., Fallopia convolvulus (L.) Á. Löve, Urtica dioica L.). High value of honey yield of autumnal melliferous plants is a caloric food just before the wintering of bees. The diversity of plant species on the balks, through a different flower structure, can provide a food base for numerous (other than bees) pollinating insects, for which balks are not only a place of feeding but also nesting. The plants weakly covered by honeybees, and many other pollinators are, among others: Fallopia dumetorum (L.) Holub, Lathyrus pratensis L., Matricaria discoidea DC., Papaver rhoeas L., Silene latifolia Poir. 
Many of therapeutic species show an influence on at least three systems of the human body (for example: digestive system, respiratory system, excretory system, immune system, nervous system and also on dermal layers of the skin). Among others, these are: Artemisia absinthium L., Ballota nigra L., Berteroa incana (L.) DC.), Centaurea cyanus L., C. scabiosa L., Chamomilla recutita (L.) Rauschert, Ch. suaveolens (Pursh) Rydb., Chenopodium album L., Cichorium intybus L., Cirsium arvense (L.) Scop., C. oleraceum (L.) Scop. and Equisetum arvense L. Out of cosmetic species there were, among others: Aegopodium podagraria L., Erigeron canadensis (L.) Cronquist, Papaver rhoeas L., Potentilla anserina L., Urtica dioica L. Seasoning herb species are, among others: Achillea millefolium L., Artemisia absinthium L., A. vulgaris L., Capsella bursa-pastoris (L.) Medik., Chamomilla recutita (L.) Rauschert, Cirsium oleraceum (L.) Scop., Crataegus monogyna Jacq., Elymus repens L., Heracleum sphondylium L., Lactuca serriola L., Pastinaca sativa L. Decorative herb species are, among others: Lysimachia nummularia L., Malva sylvestris L., Plantago lanceolata L., Oenothera biennis L. and Solidago canadensis L.

On the terrain of balks it was shown that $31 \%$ of the species belong to the group of very burdensome weeds. These species are resistant to breaking (e.g. they possess long rhizomes or a strong taproot system) and they spread quickly, which is connected with the number of yielded seeds. These are, among others: Achillea millefolium L., Aegopodium podagraria L., Anagalis arvensis L., Apera spica-venti (L.) P. Beauv, Capsella bursa-pastoris (L.) Medik., Centaurea cyanus L., Chenopodium album L., Consolida regalis S. F. Gray, Equisetum arvense L. The presence of dicotyledonous plants, strongly rooted, i.e. 32 species of weeds and 12 species of grasses (such as, for example: Cynosurus cristatus L., Dactylis glomerata L., Deschampsia cespitosa (L.) P. B., Elymus repens (L.) Gould, Lolium perenne L., Phleum pratense L.) conducive to strong sodding of subsoil, was related to the earlier use of the balk as a field track.

\section{Discussion}

Diversity of the species occurring in the agricultural landscape is caused by the presence of constructive elements such as areas used agriculturally, grassland and unused areas, to which belong drainage ditches, water canals, hedges and balks, but also biotopes of a high degree of naturalness such as fragments of forest ecosystems or afforestation. In the space-time system of the agricultural landscape it is important that there occur anthropogenic species strongly related with a given form of the object or with historical kind of the use of land (Harrach and Sauer, 2002). The studied area of the Lake District is characterized by a varied landscape structure composed between numerous hills (> $150 \mathrm{~m}$ above sea level). Fields are separated by narrow areas of forest ecosystems, large and small lakes with a long shape (Wapnica Lake, Wapnica Południowa, Sierakowskie, At Poplar, Sicko) and water ponds. The richness of so many natural elements of the landscape is conducive to the presence of various forms of environmental islands, and the diversity of sculpture facilitates the existence of numerous midfield balks. Aavik and Lira (2010) determined the main factors of plant species richness and composition in field boundaries. They surveyed the vegetation of field boundaries in organic and non-organic farms, and recorded the field boundary type and width. It was found that field boundary type and landscape structure described most of the variation in species composition of these boundaries, while organic farming had little effect. Boundary type had a specific impact on species diversity ditches enhanced 
the richness of nature-value species and suppressed agrotolerants; woody boundaries hosted only a few agrotolerant species and road verges increased the species richness of both species groups. The richness of nature-value species benefited from wider open boundaries, while narrow boundaries hosted more agrotolerant species.

A large number of fragmented plots significantly influences farmers' unwillingness to implement new technologies and innovations which could improve efficiency of agricultural production. The owners of larger rural areas consent to technological novelties and modern solution much more willingly than the owners of smaller and fragmented plots. However, in Bulgaria, the case of land fragmentation caused abandonment of the use of irrigation systems, which turned out to be unprofitable in such small areas (Penov, 2004). In the 1950s and 1960s, water conditions were regulated in the studied area, with numerous ditches and drainage channels present. The nearest surroundings of the ditches are grasslands, usually of a long shape, separating the individual areas of the fields. The undulating terrain of the research (close distance between the contours within 50-70 m) and the extensive network of drainage ditches, despite the use of intensive mechanical and chemical treatments, enabled the presence of numerous balks. Fragmentation of arable land is more and more frequently regarded as the main cause of difficulties with undertaking agricultural activity, particularly in well developed countries. Therefore, the best economic effect was achieved due to specialization and intensification of plant production. Despite many negative effects of land fragmentation, some positive features can be found in this situation in the agricultural space. It is obvious that fragmentation of the plots increases the costs of production, but lowers its risk (Dudzińska, 2012). The studied area in its north-eastern part adjoins the natural area of Ostoja Ińska (PLB 320008), and in the southern part, on a considerable length it borders with another natural area - the Ina Valley near Recz (PLH320004). Such a neighborhood between two such valuable protected areas, i.e. an area of special protection of birds and of significance for the community, makes it a cover area. Its proper functioning in the landscape is a buffer for negative external factors. At large fragmentation and dispersion of arable fields it is possible to avoid negative effects of weather anomalies such as droughts, floods, fires, hailstorms and other unexpected spatial factors (pest infestation).

As a result of large-area economy and, in considerable areas, monoculture economy significant floristic impoverishment of arable land took place, both in a direct way (field areas - segetal plants) and in an indirect way (areas of marginal habitats - seminatural way), both in a thought over way (application of agrotechnical treatments) and in a thoughtless way (devastating activities accepted). At present, the agricultural landscape undergoes treatment aiming at restoring the previous - natural gene pool (Bauer and Wing, 2010; Paudel et al., 2015). Increased biodiversity is favored by the proximity of other forms of environmental islands. $83 \%$ of the studied area was connected to field roads. A few balks neighbored with another object (for example small ponds, grasslands or excavations) or they were located nearby (up to 20-30 m).

Intensification of agricultural production leads to a threat to the habitat and biological diversity. Up to the 1990s, farmers' efforts were directed towards the elimination of weeds (Horta et al., 2015). This study also confirmed Skrajnej on the Kałuszyńska Upland (2010). Through "rapaciousness" of seeds, seedlings and cuttings, as well as increased survival of seedlings in the periods of environmental stress, weeds are treated as nutritive competitors of farm plants. Therefore, some species have been completely eradicated. The share of common and very common species amounted to 
only $8 \%$, although some were characterized by a significant degree of coverage. In the studied area, among the species with a wide range of occurrences the following were recorded: Equisetum arvense L., Elymus repens (L.) Gould, Convolvulus arvensis L., Capsella bursa-pastoris (L.) Medik. and Stellaria media (L.) Vill.). However, among these cosmopolitan species, only the couch-grass occupied larger areas.

At present, larger and larger significance is attached to diversity. Therefore, the approach to the problem of weed control changes. From the point of view of the amount of crop yields, complete elimination of weeds is not necessary in all conditions. If weed infestation is reduced to the level not threatening farm plants and economic factors are taken into consideration, the effect of diversity protection can be achieved (Gerowitt et al., 2003). In the studied area among the species threatened by extinction to various degrees only one species was observed - Consolida regalis S. F. Gray - as sporadic in association with Agropyretum repentis, and out of plants constituting the place of living and reproduction of animals, there were, among others: Chenopodium album L., Cirsium arvense (L.) Scop., Stellaria media (L.) Vill., Galium aparine L., Polygonum aviculare L., Rumex obtusifolius L., Sonchus arvensis L., Tripleurospermum inodorum (L.) Sch. Bip., Urtica dioica L. Van Acker (2009) noticed that many plant species can survive in the soil even up to a few years. If weeds did not cause loss to crop yields, they could be treated as "a good and indispensable neighbor" of the cultivated plants. Weed control and creation of the conditions limiting their reproduction and formation of seeds is conducive to farm plants. However, a negative influence of the liquidation of weeds on the functioning of the ecosystem through the disturbance of soil processes and nutritive dependences between plants, microflora and fauna cannot be avoided. However, in the studied area of the balks, the so-called weeds form communites with Apera spica-venti and Chenopodium album.

Areas classified as wasteland, including midfield balks, are a valuable habitat as a food base for bees. Mačukanović-Jocić and Jarić (2016) in their research on the role of phytocoenoses in maintaining the diversity of melliferous species, showed their greatest share (over 80\%) in the Consolido-Polygonetum avicularis. In earlier studies Jarić et al. (2013) as phytocoenoses with the highest share of melliferous species they pointed to Petasitetum hybridi (70\%). Among the species found in the analyzed areas, species constituting the core of the phytocenosis Consolido-Polygonetum avicularis, i.e. larkspur and knotgrass, have been demonstrated. However, Consolida regalis S. F. Gray appeared as sporadic species, and Polygonum aviculare L. occupied slightly larger areas, mainly in contact with the roadside. Among the listed communities, the most melliferous species (64\%) were demonstrated in one of the Lolium perenne community.

The studies by Denisow and Wrzesien (2007) on the vegetation of balks in the areas of communes near Lublin showed the presence of 214 plant species, $80 \%$ of which constituted bee nutrient taxa. The definite majority of melliferous species was connected with meadow, nitrophilous and ruderal communities. Of the species found in the midfield studied balks 67 plants showed melliferous properties. Bee nutrients of high melliferousness and the coefficients of cover (D) were, among others: Ballota nigra L. (values of honey yield $368 \mathrm{~kg} / \mathrm{ha}, \mathrm{D}-1215$ ), Melilotus officinalis (L.) Pallas (200, 1458), Medicago lupulina L. (200, 1264), Salix alba L. (150, 292), Trifolium repens $\mathrm{L}$. $(90,104)$. Considering the production of pollen, the most valuable melliferous plants commonly found in most communities were: Taraxacum officinale F. H. Wiggers coll. and Cirsium arvense (L.) Scop., occupying larger areas and already less numerous: Cichorium intybus L., Daucus carota L., Medicago lupulina L., Rubus caesius L. In the 
studied area, grass species predominated on the surface, such as: Apera spica-venti (L.) P. Beauv, Arrhenatherum elatius (L.) P. Beauv. ex. J. \& C. Presl, Dactylis glomerata L., Elymus repens L., Lolium perenne L. These species are valuable for bee-keeping due to the heavily occupied areas. This is confirmed by Ceglińska's (2008) study, which has recorded the presence of pollen grains in all honey samples. Among all taxa pollen grains present in one sample, Poaceae pollen has reached the highest frequency $(70 \%)$. The study by Link (2007) of long and narrow belts of balks in the extensively developed fields (each research area amounted to 4.1 ha) in the vicinity of Bronowice, lists 153 plant species, whereas in the intensively managed areas only 59 species. He emphasized the role of balks in the middle of intensively managed agricultural landscapes. The ecological function of these objects is not to be overestimated, even if they constitute $0.8 \%$ of the whole surface. In the analysed research area $45 \%$ of the observed flora of the balks showed melliferous properties, and these were species characterised by high melliferousness (over $300 \mathrm{~kg} / \mathrm{ha}$ ). Maintenance of a natural habitat or natural habitat elements in a farm is important for behaviour of bees in functionally differentiated communities of agroecosystems (Forrest et al., 2015). This study examined how the quality of a field boundary habitat and farming system (organic or conventional) affect species richness and abundance of diurnal lepidopterans and bumblebees in boreal agricultural landscapes. The results showed positive effects of field boundary area on lepidopteran diversity, as well as positive effects of nectar flower abundance on lepidopterans and bumblebee abundance. The results suggested that a successful conservation strategy for lepidopterans present in boreal agroecosystems depends on proper management of field boundaries, irrespective of farming regime. The results concord with a general hypothesis that the effects of organic farming might be overpowered by the effects of landscape structure in heterogeneous landscapes (Ekroos et al., 2008).

Apart from bee nutrient properties flora of the balks provides raw materials for the production of pharmaceuticals. It was proved that $75 \%$ human population benefits from therapeutic properties of herbs. Particularly precious are those gathered in the areas of high sanitary values and which are subject to the protection of biological diversity and such is the area of balks (Abbas et al., 2015). In the studied terrain 63\% of plants possessed therapeutic properties affecting at least three human ailments. They were meadows species: yarrow (with carminative, antispasmodic, anti-haemorrhagic, antiallergic properties), hogweed (shows anti-diarrheal properties, regulates digestion, is used in laryngitis and physical exhaustion) or curly dock (astringent, antidiarrheal, antibacterial, anti-anemic, detoxifying effects). Only a few of them are helpful in treating one condition. Therapeutic species that are helpful in treating many diseases predominate.

The results indicated a positive influence of integrated farming on biodiversity of herbal and bird communities in the conditions of agricultural landscape. Especially noteworthy was the positive importance of integrated meadows as the type of farmland with the highest species diversity, due to the interconnectedness of all components of the ecosystem (Štefanová and Šálek, 2014). The flora of the balks of the studied area is structurally diverse also in terms of heights. Thus, it enables convenient conditions for the creation of ecological niches for animals staying temporarily or permanently in the fields. The highest layer, although only in few boughs, is trees. Mainly it was a white willow with the height (on non-topped specimens) of up to $16 \mathrm{~m}$. Single specimens of shrub were found more often for example (up to $5 \mathrm{~m}$ in height) - elder. In local 
depressions of the studied area, herbaceous plants grew up to $1.5 \mathrm{~m}$ (mugwort or nettle). The remaining sward was definitely lower, except for inflorescences of some grasses (oat-grass, tufted hair grass) or dicotyledons (common chicory, evening primrose, melilot, mallow).

Halada et al. (2011) identified the habitat types listed in the Habitats Directive Annex I that require low-intensity agricultural management for their existence. They discussed that habitat types for which either doubts remain on their dependence on agricultural management, or the relation to extensive farming practices exists only in part of their area of distribution in Europe or under certain site conditions, respectively. Assessments of the conservation status of habitats of European Importance by 25 EU Member States in 2007 showed that habitats identified in the study as depending on agricultural practices had a worse status than non-agricultural habitats.

Plant communities in the area of balks constitute poor phytocoenoses dominated mainly by grasses (for example Convolvulo arvensis-Agropyretum repentis), the participation of which is linked with a high level of fertilization in in the neighbouring fields. In the studied area 14 species of grasses were observed, out of which 6 constituted communities. These were: communities with Apera spicae-venti from Stellarietea mediae class (crop fields communities), association Agropyretum repentis from Agropyretea intermedio-repentis class (semi-perilous pioneer communities), association Arrhenatheretum elatioris from Molinio-Arrhenatheretea class, communities with Dactylis glomerata, communities with Lolium perenne, communities with Agrostis capillaris (semi-natural and anthropogenic turf meadow and pasture communities). Literature data also prove that on edge belts there is a slight number of segetal species from class Stellarietea mediae (Denisow and Wrzesień, 2007). However, Gargała and Trąba (2014) conducted studies in the south of Poland (Podkarpacie Subcarpathia) and showed higher participation of such species (to 50\%). In the research area of balks in Ińsko Lakeland (Pojezierze Ińskie) segetal species from class Stellarietea mediae constituted 14\%. Among them two species: Apera spica-venti (L.) P. Beauv and Chenopodium album L. dominated in communities.

Balks are treated as linear elements in the strongly changed landscape which particularly refers to the area of arable fields. They are under strong pressure due to their small surface in relation to a very long line of adjacency, which results in poverty of plant species (Ratyńska, 2011). The width of the examined balks in the Ińsko Lakeland ranged from 50 to $70 \mathrm{~m}$. The average length of short/long balks was $246 \mathrm{~m}$ and $916 \mathrm{~m}$ respectively, at a minimum of $76 \mathrm{~m}$ and $522 \mathrm{~m}$ respectively, and a maximum of $421 \mathrm{~m}$ and $2552 \mathrm{~m}$. No relationship was observed between the increase in the width of the balks and the increase in the number of plants present there. In order to sustain biodiversity and maintain species, propositions difficult to accept can be met, such as undersowing weeds and sowing worse cleaned seeds and leaving some weeds in the field. Such a situation takes place in Western Europe countries of higher intensification of agriculture. In relation to this, the choice of undersown segetal plants becomes significant. An important criterion of the selection of these plants will be high reliability and therapeutic properties. Fast urbanization, habitat destruction, over-grazing and overharvesting of medicinal plants has resulted in a loss of native species and traditional knowledge among the local communities. Efforts are required to conserve habitat as well as indigenous knowledge of the study area (Abbas et al., 2015).

The clearly significant effect of study by Tuomisto et al. (2012) is somewhat in contrast with the contradictory findings obtained in some areas of Western and Eastern 
Europe. In Western Europe, such studies could probably have led to ambiguous results because the landscape devastation there had reached a much higher level, and thus regeneration of communities of organisms is a long-term matter and requires synergistic interaction of multiple positive factors. The studied area of the lake district is characterized by average soil quality, strongly undulating terrain and locally diversified humidity conditions, which do not induce farmers to significantly increase the anthropogenic pressure associated with the cultivation of these fields.

Losses of biological diversity which result from the land use can lower their ecological role (Hooper et al., 2012). Bee reactions are not equally negative (Winfree et al., 2009) because the mosaic of seminatural and arable habitats which differ as regards vegetation, soil and water conditions compensates transformations in the economic production space, which illustrates that these habitats are richer as regards biodiversity by $10.5 \%$ (Julier and Roulston, 2009). The selection of therapeutic species should take into account their place of origin (the areas under protection) and local soil-weather conditions. Plant undersowing can be regarded as highly beneficial in the case of species particularly threatened by extinction in a given area. For this reason it is possible to sustain the natural state of vegetation and propagation of useful organisms. This is important from the point of view of environmental protection and can be of larger significance if the plants are grown in large areas. Relatively well maintained balks characterised by significant biodiversity in the area of Ińsko Lakeland can constitute a good point of reference to determine a beneficial specific composition on soils representing average soil conditions for cultivation in Europe.

\section{Conclusions}

1. It was shown that in the areas of an arable surface characteristic of average farms as regards their size in the European Union, the size of arable land and the length of balks related with it had an influence on phytodiversity. Despite the fact that the number of phytocoenoses was larger on shorter balks, their specific poverty did not affect biodiversity significantly.

2. The presence of a large number of melliferous species influenced not only phytodiversity of balks (102 species), but it resulted in the improvement of nutritive conditions, among others, for bees. Variety of plant structure (trees, shrubs, herbs), considerable flowering length (from March to October) and various flower construction of the so-called field weeds can provide a food base for many pollinators, including honeybees.

3. A larger number of plant species on long balks, including also melliferous (67) and therapeutic species (64), proves correct management of the production space in a long time period.

4. More and more climatic changes are pushing us to undertake further, more detailed studies of the physical factors and flora of the balks that shape the surrounding biodiversity.

Acknowledgements. Authors thanks Marek Pogorzelec for valuable comments in assessing the frequency of bees flying on selected plant species. 


\section{REFERENCES}

[1] Aavik, T., Lira, J. (2010): Quantifying the effect of organic farming, field boundary type and landscape structure on the vegetation of field boundaries. - Agriculture, Ecosystems and Environment 135: 178-186.

[2] Abbas, G., Abbas, Q., Wali Khan, S., Hussain, I., Najumal-ul-Hassan, S. (2015): Medicinal plants diversity and their utilization in Gilgit Region. - International Journal of Plant and Soil Science 5(4): 234-248.

[3] Bauer, D. M., Wing, I. S. (2010): Economic consequences of pollinator declines: a synthesis. - Agricultural and Resource Economics Review 39(3): 368-383.

[4] Borzyszkowski, J., Marczak, M., Zarębski, P. (2016): Spatial diversity of tourist function development: the municipalities of Poland's West Pomerania Province. - Acta Geographica Slovenica 56(2): 267-276.

[5] Ceglińska, K. (2008): Anemophilous plant pollen in spring specific honeys from the Rzeszów area. - Acta Agrobotanica 61(1): 59-64.

[6] Denisow, B., Wrzesień, M. (2007): The anthropogenic refuge areas for bee flora in agricultural landscape. - Acta Agrobotanica 60(1): 147-157.

[7] Di Falco, S., Peno, I., Aleksiev, A., van Rensburg, T. M. (2010): Agrobiodiversity, farm profits and land fragmentation: Evidence from Bulgaria. - Land Use Policy 27(3): 763771.

[8] Directive (2004): Directive of the European Parliament and of the Council Establishing a Framework for the Protection of Soil and Changing. - Directive 2004/35/WE (in Polish).

[9] Dobrzański, A. (2009): Expertise. Biological and Agronomic Aspects of the Regulation of Weed. - The European Union under the European Social Fund Development of innovative potential of members of the Scientific Network "Agroengineering for the development of sustainable agriculture, agri-food industry and rural areas". AgEngPol, Skierniewice (in Polish).

[10] Dudzińska, M. (2012): Patchwork of agricultural land as a factor affecting rural space. Infrastructure and Ecology of Rural Areas 2: 45-56 (in Polish).

[11] Dzwonko, Z. (2007): Guide to Phytosociological's Research. - Sorus, Poznań-Kraków (in Polish).

[12] Ekroos, J., Piha, M., Tianen, J. (2008): Role of organic and conventional field boundaries on boreal bumblebees and butterflies. - Agriculture, Ecosystems and Environment 124(34): $155-159$.

[13] Feiza, V., Feizienè, D., Jankauskas, B., Jankauskienė, G. (2008): The impact of soil management on surface runoff, soil organic matter content and soil hydrological properties on the undulating landscape of Western Lithuania. - Zemdirbyste-Agriculture 95(1): 3-21.

[14] Forrest, J. R. K., Robbin, W. T., Kremen, C., Williams, N. M. (2015): Contrasting patterns in species and functional-trait diversity of bees in an agricultural landscape. Journal of Applied Ecology 52: 706-715.

[15] Gamrat, R. (2012): Studies on the Midfield Variety of Environmental Islands in the Basin of the Ina. - West Pomeranian University of Technology, Szczecin (in Polish).

[16] Gargała, M., Trąba, C. (2014): Segetal weeds in contemporary open landscapes in the municipality of Markowa. - Landscape Architecture 1: 74-85 (in Polish).

[17] Gerowitt, B., Bertke, E., Hespelt, S. K., Tute, C. (2003): Toward a multifunctional agriculture - weeds as ecological goods ? - Weed Research 43: 227-235.

[18] Halada, L., Evans, D., Romão, C., Petersen, J. E. (2011): Which habitats of European importance depend on agricultural practices? - Biodiversity and Conservation 20(11): 2365-2378.

[19] Harrach, T., Sauer, S. (2002): Zeitliche und räumliche Aspekte der Beziehung von Landwirtschaft und Naturschutz aus bodenkundlicher Sicht. - In: Akademie für die 
Ländlichen Räume Schleswig-Holsteins (ed.) Naturschutz und Landwirtschaft. - Neue Überlegungen und Konzepte. ALR, Eckernförde (in German), pp. 130-148.

[20] Hooper, D. U., Adair, E. C., Cardinale, J. B., Byrnes, J. E. K., Hungate, B. A., Matulich, K. L. (2012): A global synthesis reveals biodiversity loss as a major driver of ecosystem change. - Nature 486: 105-108.

[21] Horta, A. B., Malone, B., Stockmann, U. B., Minasny, B., McBratney, A. B., Pallasser, R., Pozza, L. (2015): Potential of integrated field spectroscopy and spatial analysis for enhanced assessment of soil contamination: a prospective review. - Geoderma 241-242: 180-209.

[22] Jarić, S., Mačukanović-Jocić, M., Mitrović, M., Pavlović, P. (2013): The melliferous potential of forest and meadow plant communities on Mount Tara (Serbia). Environmental Entomology 42(4): 724-732.

[23] Julier, H. E., Roulston, T. H. (2009): Wild bee abundance and pollination service in cultivated pumpkins: farm management, nesting behavior and landscape effects. - Journal of Economic Entomology 102: 563-573.

[24] Karg, J. (2003): Field bushes, Buffer Zones and Patches. - Bookcase of the National Agri-environmental Program, Advertising and Publishing Agency „Skigraf”, Warszawa (in Polish).

[25] Karg, J. (2005): The role of Trees in the Agricultural Landscape. - In: Woźniak, E. (ed.) Materials and Scientific Conference, "Roadside trees, life threatening?" Kościański Cultural Center in Kościan, 28.06.2005. Road Traffic Section of the KPP in Kościan and Association for the Prevention of Road Accidents "Stop Death" (in Polish).

[26] Kazlauskaite-Jadzevice, A., Marcinkonis, S., Baksiene, E. (2016): Energy value of biomass produced on various land uses in a sandy loam Haplic Luvisol. - ZemdirbysteAgriculture 103(2): 143-150.

[27] Kędziora, A., Kujawa, K., Gołdyn, H., Karg, J., Bernacki, Z., Kujawa, A., Bałazy, S., Oleszczuk, M., Rybacki, M., Arczyńska-Chudy, E., Tkaczuk, C., Łęcki, R., Szyszkiewicz-Golis, M., Pińskwar, P., Sobczyk, D., Andrusiak, J. (2012): Impact of Land-Use and Climate on Biodiversity in an Agricultural Landscape. -In: Lameed, G. A. (ed.) Biodiversity Enrichment in a Diverse World. - InTech, Rijeka, pp. 281-336.

[28] Kinderiene, I., Karcauskiene, D. (2016): Assessment of soil erosion processes as influenced by different land-use systems on hilly rolling landscape of Western Lithuania. - Zemdirbyste-Agriculture 103(4): 339-346.

[29] Link, M. (2007): Sustainable protection of biodiversity in central Poland - thoughts regarding a future model ('leitbild') for the development of traditional agricultural. Monitoring of the Natural Environment 8: 9-16.

[30] Lipiński, M. (2010): Bees' Benefits. Pollination and Melliferity of Plants. - Universal Publishing House of Agriculture and Forestry, Warsaw, Sądecki Bartnik Publishing House, Stróże (in Polish).

[31] Loster, S. (1991): Floristic richness in an agricultural landscape and the maintenance of natural and semi-natural island communities). - Fragmenta Floristica et Geobotanica 36(2): 427-457 (in Polish).

[32] Noga, K. (2005): Methodology for evaluating the spatial structure of farm land before and after the merge. - Papers of the Society of Rural Development, Rzeszów 5: 30-47 (in Polish).

[33] Mačukanović-Jocić, M. P., Jarić, S. V. (2016): The melliferous potential of apiflora of southwestern Vojvodina (Serbia). - Archives of Biological Sciences, Belgrade 68(1): 819.

[34] Paudel, Y. P., Mackereth, R., Hanley, R., Qin, W. (2015): Honey bees (Apis mellifera L.) and pollination issues: current status, impacts, and potential drivers of decline. - Journal of Agricultural Science 7(6): 93-109.

[35] Pe'er, G., Dicks, L. V., Visconti, P., Arlettaz, R., Báldi, A. (2014): EU agricultural reform fails on biodiversity. - Science 344: 1090-1092. 
[36] Penov, I. (2004): The use of irrigation water in Bugaria's Plovdiv region during transition. - Journal of Environmental Management 34(2): 304-313.

[37] Pogorzelec, M. (2018): Honey Plants. - Sądecki Bartnik Publishing House, Gorzów Wielkopolski (in Polish.

[38] Ratyńska, H. (2002): Environmental Islands as an Element of Landscape, Typology and Diversity of Vegetation. - In: Banaszak, J. (ed.) Environmental Islands. Biodiversity and Typology Tests. - Wyd. Akademii Bydgoskiej, Bydgoszcz (in Polish), pp. 239-260.

[39] Ratyńska, H. (2011): Vegetation accompanying communication roads. - Ecology and Technology 19(3A): 5-15.

[40] Skrajna, T. (2010): Medicinal plants in segetal communities of the Kaluszynska Upland. - Plant Breeding and Seed Science 61: 105-114.

[41] Štefanová, M., Šálek, M. (2014): Effects of integrated farming on herbal and bird species diversity in czech agricultural landscapes. - Polish Journal of Ecology 62: 147-162.

[42] Symonides, E. (2010): The importance of ecological connections in the agricultural landscape. - Water-Environment-Rural Areas 10 4(32): 249-263 (in Polish).

[43] Tuomisto, H. L., Hodge, I. D., Riordan, P., Macdonald, D. W. (2012): Does organic farming reduce environmental impacts? - Journal of Environmental Management 112: 309-320.

[44] van Acker, R. C. (2009): Weed biology serves practical weed management. - Weed Research 49: 492-502.

[45] Winfree, R., Aguilar, R., Vázquez, D. P., LeBuhn, G., Aizen, M. A. (2009): A metaanalysis of bees' responses to anthropogenic disturbance. - Ecology 90: 2068-2076. 